\title{
Eskişehir Osmangazi Üniversitesi Tıp Fakültesi Son Sınıf Öğrencilerinin Halk Sağlı̆̆ı Stajını Dĕgerlendirmeleri
}

\section{Evaluation of Public Health Internship of Eskişehir Osmangazi University Medical Faculty Senior Students}

\author{
Sevil Aydoğan (ORCID ID: 0000-0002-7314-5900) \\ Muhammed Fatih Önsüz (ORCID ID: 0000-0001-7234-3385) \\ Burhanettin Işılkl (ORCID ID: 0000-0003-2902-9328) \\ Selma Metintaş (ORCID ID: 0000-0002-5002-5041) \\ Eskişehir Osmangazi Üniversitesi Tıp Fakültesi Halk Sağlığı Anabilim Dalı \\ Sorumlu Yazar: Sevil AYDOĞAN \\ Eskişehir Osmangazi Üniversitesi Tıp Fakültesi Halk Sağlığı Anabilim Dalı \\ Yazışma adresi: Eskișehir Osmangazi Üniversitesi Tıp Fakültesi Halk Sağlığı Anabilim Dalı/Odunpazarı/Eskişehir \\ Telefon: 05363492136 E-posta: aydogan.sevil@gmail.com
}

Anahtar Sözcükler:

Halk Sağlığı, staj, değerlendirme

Keywords:

Public Health, internship, evaluation

Gönderilme Tarihi Submitted:28.06.2019 Kabul Tarihi Accepted: 14.10.2019
ÖZET:

Amaç: Çalışmanın amacı, Eskişehir Osmangazi Üniversitesi (ESOGÜ) Tıp Fakültesi Dönem VI öğrencilerinin, Halk Sağlığı stajı içerisinde aldıkları teorik ve uygulamalı eğitimin değerlendirilmesidir.

Gereç ve Yöntem: Çalışma, 2017-2018 eğitim öğretim yılında Eskişehir Osmangazi Üniversitesi Tıp Fakültesi'nde Halk Sağlığı staj1 yapan altıncı sınıf öğrencilerinde yürütülen bir araştırmadır. Çalışma iki aşamada gerçekleştirildi. Veri toplama amacıyla, Halk Sağlığı stajında yapılan uygulamaları içeren bir anket form hazırlandı. Çalışma grubunu, bir yıl boyunca Halk Sağlığı stajı alan öğrencilerin tümü (184) oluşturdu. Aynı anket form öğrencilere staj başında ve staj sonunda uygulandı. Staj başındaki ankette öğrencilerin eğitimlerin faydalı olup olmayacağına dair düşünceleri, staj sonundaki ankette ise eğitimleri aldıktan sonra, faydalı bulup bulmadıklarına dair düşünceleri değerlendirildi. Verilerin değerlendirilmesinde, bağımlı örneklerin karşılaştırmasında nicel verilerde Wilcoxon ve nitel verilerde Ki-kare testleri kullanıldı. İstatistiksel anlamlılık değeri olarak $\mathrm{p}<0.05$ kabul edildi.

Bulgular: Öğrencilerin staj bitiminde eğitimlerin faydalı olma durumu ile ilgili verdikleri puan $(53.4 \pm 9.6)$, staj başlangıcındaki puana $(51.5 \pm 7.0)$ göre anlamlı düzeyde yüksekti $(\mathrm{p}=0.002)$.

Künye: Aydoğan S, Önsüz M, Işıklı B, Metintaş S. Eskişehir Osmangazi Üniversitesi Tıp Fakültesi Son Sınıf Öğrencilerinin Halk Să̆lı̆̆ Stajını Değerlendirmeleri. Tıp Ĕ̌itimi Dünyası. 2020;19(57):98-108 
Öğrencilerin \% 62.9'u staj başlangıcında stajdan memnun kalacağını düşünürken, staj sonunda memnun kaldığını belirten öğrenci yüzdesi \% 73.1 olarak saptand $1(\mathrm{p}<0.001)$.

"'Bilimsel araştırma süreci" ve "teorik bilgi oturumları" gruplarındaki uygulamalardan memnuniyet staj sonunda, staj başlangıcına göre daha yüksek bulundu $(\mathrm{p}<0.001)$. 'Sağlık hizmetleri ve uygulamalar" grubundaki uygulamalardan memnuniyet ise staj sonunda, staj başlangıcına göre daha düşük bulundu $(p=0.002)$.

Sonuç: Öğrencilerin yaklaşık dörtte üçünün Halk Sağlığı stajından memnun kaldığı bulundu. Staj geneline verilen puanların toplamı, staj sonunda staj başlangıcına göre artış gösterdiğinden dolayı, Halk Sağlığı stajının genel olarak öğrencilerin beklentilerini karşıladığı sonucuna varıldı.

\section{Abstract:}

Background: The aim of this study is to evaluate the theoretical and practical education of 6th grade students of Eskişehir Osmangazi University Faculty of Medicine in Public Health Internship.

Methods: Study was conducted in two stages with senior students in Public Health Internship of Eskişehir Osmangazi University Faculty of Medicine in 2017-2018 academic year. Study questionnaire was prepared including the practices performed in Public Health Internship. The study group consisted of all students(184) who had internship along one year. The same questionnaire was applied both at the beginning and end of the internship. Students' opinions about whether the trainings would be useful were evaluated at the beginning of the internship and their thoughts about whether the trainigs were useful or not were evaluated at the end. Chisquare and Wilcoxon tests were used to compare dependent samples. Statistical significance was accepted as $p<0.05$.
Results: The score(53.4 \pm 9.6$)$ about the beneficial of trainings at the end of the internship was significantly higher than at the beginning of the internship score(51.5 7.0, $p=0.002)$. At the beginning of the internship $62.9 \%$ of the students thought that they would be satisfied with the internship while at the end of the internship the percentage of satisfied students was $73.1 \%(p<0.001)$. At the end of the internship satisfaction with the applications in "scientific research process" and "theoretical knowledge sessions" groups were higher than the beginning of the internship $(p<0.001)$. At the end of the internship satisfaction with the applications in "health services and practices" group were lower than the beginning of the internship $(p=0.002)$.

Conclusions: Approximately three-quarters of students were satisfied with the Public Health internship. As the total of the scores given increased compared to the beginning of the internship, it was concluded that the internship generally met the students' expectations.

\section{Giriş}

T1p eğitiminin amacı, hem hastalar hem de toplum için koruyucu ve tedavi edici hizmetleri kaliteli bir şekilde verebilmek, tüm insanların sağlık düzeyini yükseltebilmek ve sağlıklı yaşamalarını sağlayabilmek için yetenekli ve yeterli hekimler yetiştirmektir (1). Tıp fakültesi müfredatlarının, birinci basamak sağlık hizmetlerinin sunulmasında gerekli bilgi ve beceriyi sağlamakta yetersiz kaldığ1, özellikle pratik becerilerin geliştirilemediği bildirilmektedir (2). Tıp fakültesi eğitim müfredatı içinde, hekim adaylarının birinci basamak sağlık hizmeti sunan kuruluşlara hazırlandığı, koruyucu hekimlik eğitimi aldıkları ve ilgili çalışmalara aktif olarak katıldıkları staj Halk Sağlığı stajıdır $(1,3)$.

Winslow halk sağlığını; örgütlenmiş toplum 
çabaları sonucunda bireylere sağlık eğitimi vererek, çevre sağlığı koşullarını düzelterek, bulaşıcı hastalıkları önleyerek, hastalıkların erken tanı ve etkin tedavisini sağlayarak, sağlık örgütleri kurarak, toplumsal çalışmaları her bireyin sağlığını sürdürecek bir yaşam düzeyini sağlayacak biçimde geliştirerek; hastalıklardan korunmayı, yaşamın uzatılmasını, beden ve ruh sağlığı ile çalışma gücünün artırılmasını amaçlayan bir bilim ve sanat olarak tanımlamıştır (4). Klinik tıp bireysel düzeyde hastalığın teşhisi, tedavisi, sağlığı geliştirme, ağrı ve sıkıntıyı hafifletme ile ilgilenirken; Halk Sağlığı, toplum sağlığının geliştirilmesi ve sağlık alanındaki eşitsizliklerin azaltılması ile ilgilenir. Halk Sağlığının hedefleri sağlık hizmetleri, sağlığ1 koruma ve sağlığın iyileştirilmesi olmak üzere üç başlık altında toplanabilir. Sağlık hizmetleri önleme, tedavi ve bakım için yüksek kaliteli hizmetleri organize etme ve uygulanmasını sağlama ile ilgilidir. Sağlığ1 koruma, Halk Sağlığı acil durumları dahil olmak üzere bulaşıcı hastalık riskleri ve çevresel tehlikeleri kontrol etmek için alınan önlemleri içerir. Sağlığın iyileştirilmesi ise hastalıkları önlemek ve sağlığı geliştirmek amacıyla yapılan toplumsal müdahaleleri kapsar (5). Halk Sağlığı epidemiyoloji, demografi, sağlık ekonomisi, biyoistatistik, sosyoloji, psikoloji ve yönetim bilimi gibi pek çok disiplinle etkileşim içindedir. Kanıta dayalı tıbbı kullanarak sağlık, hastalık ve tedavi kavramlarına toplumsal bakış açısıyla bakmak, sağlığın teşviki, geliştirilmesi ve hastalıkların önlenmesini sağlamak, toplumun sağlık ihtiyaçlarını belirlemek ve kaynak dağılımı yapmak Halk Sağlığının temel uğraşlarıdır. Bu bağlamda Halk Sağlığının temel sağlık hizmetleri, bulaşıcı hastalıkların kontrolü, salgın yönetimi, kronik hastalıkların yönetimi, iş sağlığı, çocuk sağlığ 1 , okul sağlı̆̆ 1 , çevre sağlığı, literatür tarama, sağlık verileri toplayıp analiz etme ve istatistik gibi pek çok konusu vardır. Zaman içinde toplumun sağlık sorunları değişmektedir. Günümüzde artan yaşlı nüfusla beraber kronik hastalıklar artmaktadır. Küresel sağlık çalışanları işgücü içinde de özelikle kronik hastalıklar hakkında yetkinlik kazanan halk sağlıkçıların önemi artacaktır (5-8).

Halk Sağlığı stajının amacı, sağlık ve hastalık kavramlarına toplumsal pencereden bakan, hizmet vereceği toplumu tanıyan ve öncelikli sağlık sorunlarını belirleyebilen, bu sorunlara çözüm önerileri geliştirebilen, birinci basamak sağlık hizmetlerini bilen ve yürütebilen hekimler yetiştirmektir (1, 3, 9, 10). Hekim adaylarına içinde hizmet verecekleri sağlık sisteminin tanıtılması, Halk Sağlığı bakış açısının kazandırılması ve Halk Sağlığı uygulamalarının benimsetilmesi için halk sağlığı stajı oldukça önemlidir $(3,11)$.

Çalışmanın amacı, Eskişehir Osmangazi Üniversitesi (ESOGÜ) Tıp Fakültesi Dönem VI öğrencilerinin, Halk Sağlığı stajı içerisinde aldıkları teorik ve uygulamalı eğitimin değerlendirilmesidir.

\section{Gereç ve Yöntem}

Çalışma, 2017-2018 eğitim öğretim yılında ESOGÜ Tıp Fakültesi'nde Halk Sağlığı stajı yapan altıncı sınıf öğrencilerinde yürütülen gözlemsel tarzda, prospektif bir araştırmadır. Halk Sağlığı stajına başladıkları ilk gün öğrencilerden yapılandırılmış bir form ile beklentileri alınmış, stajın sonunda ise bu beklentilerin ne kadarının karşılandığ 1 değerlendirilmiştir.

ESOGÜ Tıp Fakültesi'nde altı yıllık tıp eğitiminin son yılında verilen Halk Sağlığı stajının süresi 2 aydır. Öğrenciler bu süre içerisinde eğitim araştırma bölgesinde bulunan Toplum Sağlı̆̆ı Merkezi (TSM) ve bağlı birimlerinde uygulamalı eğitim almakta, 
epidemiyolojik bir araştırma planlama, uygulama, raporlama ve sunma çalışmalarına katılmakta ve belirlenen konularda seminer hazırlayıp sunmaktadırlar.

Çalışmanın yürütülmesi için gerekli etik kurul izni ESOGÜ Girişimsel Olmayan Klinik Araştırmalar Etik Kurulu'ndan 29.01.2018 tarihli ve 80558721/G-31 sayılı karar ile alındı. Çalışma süresince Halk Sağlığı stajı alan öğrencilere çalışmanın konusu ve amacı anlatıldı. Çalışmaya katılmayı kabul edenlerden sözlü onam alındı. Bir eğitim öğretim yılı boyunca staj alan öğrencilerin tümüne ulaşıldı, çalışma grubunu 184 öğrenci oluşturdu.

Veri toplama amacıyla, Halk Sağlığı stajında yapılan uygulamaları içeren 14 önermeden oluşan bir anket form hazırlandi. Staj içerisindeki uygulamalar ' 'bilimsel araştırma süreci", "sağlık hizmetleri ve uygulamalar" ve "teorik bilgi oturumları" olmak üzere 3 ana gruba ayrıld1. Ankette bulunan literatür tarama becerisi, anket hazırlama becerisi, araştırma verisi değerlendirme, makale yazma becerisi ve makale sunma oturumunun faydasına yönelik önermeler "'bilimsel araştırma süreci”" başlığı altında toplandı (5 önerme). Meslektaş eğitim toplantısı, Sağlık Müdürlüğü tanıtım oturumu, sağlık çalışanlarının karşılaşabileceği şiddete yönelik oturum ve TSM çalışmalarının faydasını değerlendirmek için hazırlanan önermeler "sağlık hizmetleri ve uygulamalar" başlığı altında toplandı (4 önerme). Asistan destekli seminer hazırlama, etkin seminer sunma becerisi, salgın senaryosu çözme oturumu, TUS sorularını çözme oturumu ve bölümdeki seminerlerin faydasını değerlendirmeye yönelik hazırlanan önermeler ise ' teorik bilgi oturumları" başlığı altında toplandı (5 önerme). Staj başlangıcında uygulanan anketteki önermeler, belirtilen bu 14 uygulamanın her biri için “faydalı olacağını düşünüyorum”, staj sonunda uygulanan anketteki önermeler ise yapılan bu 14 uygulamanın her biri için "faydalıydı" şeklinde düzenlendi. Önermelere verilebilecek cevaplar "tamamen katıliyorum"dan "tamamen katılmiyorum"a kadar değişen beşli Likert tipindedir. Her bir önerme için verilebilecek puan 1-5 arasında değişmekte olup, formun tümüne verilebilecek puan 14-70 arasındadır. Bilimsel araştırma süreci grubuna verilebilecek toplam puan 5-25, sağlık hizmetleri ve uygulamalar grubuna verilebilecek toplam puan 4-20, teorik bilgi oturumları grubuna verilebilecek toplam puan ise 5-25 arasındadır. Anket formunun iç tutarlılığını gösteren Cronbach Alpha değeri 0.869 olarak bulundu.

Hazırlanan anket öğrencilere eğitimlerin faydalı olup olmayacağına dair düşüncelerini değerlendirmek amaciyla staj başında ve eğitimlerin fayda sağlayıp sağlamadığına dair düşüncelerini değerlendirmek amacıyla staj bitiminde uyguland.

Ayrıca öğrencilerin beşli Likert tipindeki önermelere verdikleri yanitlardan yararlanılarak, staj başında ve staj sonundaki memnuniyet yüzdeleri hesaplandi. Her bir önerme için "tamamen katılıyorum" ve "katıliyorum" yanıtını verenler o uygulamadan memnun, "kararsızım", "katılmiyorum" ve "tamamen katılmıyorum" yanıtını verenler ise memnun değil olarak kabul edildi. Her bir uygulamadan memnun olan öğrenci sayılarının toplanıp, verilebilecek toplam cevap sayısına bölünmesiyle staj genelinden memnuniyet yüzdesi hesapland1. Aynı yöntemle "bilimsel araştırma süreci”, "teorik bilgi oturumları" ve "sağlık hizmetleri ve uygulamalar" grupları için de memnuniyet yüzdesi hesapland.

Elde edilen verilerin analizi, SPSS (versiyon 24) istatistik paket programı ile yapıldı. Verilerin normal dağılıma uygunluğu Shapiro Wilk testi 
ile test edildi ve normal dağılıma uymadığ1 görüldü. Bundan dolayı, bağımlı örneklerin karşılaştırmasında nicel verilerde Wilcoxon ve nitel verilerde Mc Nemar testleri kullanıldı. İstatistiksel anlamlılık değeri olarak $\mathrm{p}<0.05$ kabul edildi.

\section{Bulgular}

Halk Sağlığı stajı başlangıcında, Halk Sağlığı stajı süresince alınacak eğitimlerin faydalı olup olmayacağına dair düşünceleri değerlendirmede verilen toplam puan 17-70 arasında değişmekte olup, ortalama 51.5 \pm 7.0 idi (ortanca 52.0). Staj bitiminde ise eğitimlerin fayda sağlayıp sağlamadığına dair düşüncelerin değerlendirilmesinde verilen toplam puan 1470 arasında değişmekte olup ortalama 53.4 \pm 9.6 idi (ortanca 55.5). Öğrencilerin staj sonu değerlendirme anketine verdikleri puanlar daha yüksek saptandı $(\mathrm{p}=0.002)$.

"Bilimsel araştırma süreci" ve "teorik bilgi oturumları" gruplarına verilen toplam puanlar, staj bitiminde staj başlangıcına göre daha yüksek, "sağlık hizmetleri ve uygulamalar" grubuna verilen toplam puan ise staj bitiminde daha düşük saptand1 (sırasıyla $\mathrm{p}<0.001$, $\mathrm{p}=0.001, \mathrm{p}=0.003$ ). Anketteki tüm önermeler tek tek incelendiğinde salgın senaryosu çözme $(p=0.015)$, etkin seminer sunma $(p=0.007)$, literatür tarama $(\mathrm{p}<0.001)$, anket hazırlama $(p=0.044)$, araştırma verisi değerlendirme $(p=0.004)$, makale yazma $(p<0.001)$ ve sunma becerileri kazanma $(\mathrm{p}<0.001)$, bölümde yapılan seminerlerin faydası $(p=0.006)$ ve

\begin{tabular}{|c|c|c|c|}
\hline & $\begin{array}{c}\text { Staj } \\
\text { başlangıcinda } \\
\text { uygulanan } \\
\text { anketteki } \\
\text { puan } \\
\text { ortalaması } \pm \text { SD } \\
\end{array}$ & $\begin{array}{l}\text { Staj bitiminde } \\
\text { uygulanan } \\
\text { anketteki } \\
\text { puan } \\
\text { ortalaması } \pm \text { SD }\end{array}$ & $\mathbf{z} ; \mathbf{p}^{*}$ \\
\hline 1. Bilimsel Araştırma Süreci & $17.7 \pm 3.2$ & $19.5 \pm 4.0$ & $5.409 ;<0.001$ \\
\hline Literatür tarama becerisi & $3.7 \pm 0.8$ & $4.1 \pm 0.8$ & $4.666 ;<0.001$ \\
\hline Anket hazırlama becerisi & $3.7 \pm 0.8$ & $3.8 \pm 0.9$ & $2.017 ; 0.044$ \\
\hline Araștırma verisi değerlendirme & $3.6 \pm 0.8$ & $3.9 \pm 0.9$ & $2.857 ; 0.004$ \\
\hline Makale yazma becerisi & $3.3 \pm 0.9$ & $3.9 \pm 0.9$ & $5.409 ;<0.001$ \\
\hline Makale sunma oturumu & $3.4 \pm 0.8$ & $3.8 \pm 1.0$ & $4.587 ;<0.001$ \\
\hline $\begin{array}{l}\text { 2. Sağlık Hizmetleri ve } \\
\text { Uygulamalar }\end{array}$ & $15.5 \pm 2.6$ & $14.6 \pm 2.9$ & $3.001 ; 0.003$ \\
\hline Meslektaş eğitim toplantıs1 & $4.0 \pm 0.7$ & $3.8 \pm 0.9$ & $2.418 ; 0.016$ \\
\hline Sağlık Müdürlüğü tanıtım oturumu & $3.7 \pm 0.8$ & $3.7 \pm 0.8$ & $0.190 ; 0.850$ \\
\hline $\begin{array}{l}\text { Sağlık çalışanlarının } \\
\text { karşılaşabileceği şiddete yönelik } \\
\text { oturum }\end{array}$ & $4.0 \pm 0.9$ & $3.6 \pm 1.0$ & $3.943 ;<0.001$ \\
\hline TSM çalışmaları & $3.7 \pm 0.9$ & $3.5 \pm 1.2$ & $2.471 ; 0.013$ \\
\hline 3. Teorik Bilgi Oturumları & $18.3 \pm 2.8$ & $19.3 \pm 3.8$ & $3.271 ; 0.001$ \\
\hline Asistan destekli seminer hazırlama & $3.5 \pm 0.9$ & $3.6 \pm 1.2$ & $0.251 ; 0.802$ \\
\hline Etkin seminer sunma becerisi & $3.5 \pm 0.8$ & $3.7 \pm 1.0$ & $2.708 ; 0.007$ \\
\hline Salgın senaryosu çözme oturumu & $3.9 \pm 0.9$ & $4.1 \pm 0.9$ & $2.424 ; 0.015$ \\
\hline TUS soruları çözme oturumu & $3.8 \pm 1.1$ & $4.0 \pm 1.0$ & $2.671 ; 0.008$ \\
\hline Bölümdeki seminer oturumları & $3.5 \pm 0.8$ & $3.8 \pm 0.9$ & $2.751 ; 0.006$ \\
\hline $\begin{array}{l}\text { Staj Değerlendirme Ölçeği Toplam } \\
\text { Puanı }\end{array}$ & $51.5 \pm 7.0$ & $53.4 \pm 9.6$ & $3.061 ; 0.002$ \\
\hline
\end{tabular}

*Wilcoxon testi ile bulunan değer

Tablo 1. Çalışma grubunun Halk Sağlığı stajındaki uygulamalar ve staj geneline verdikleri puanların staj başlangıcı ve bitiminde karşılaştırılması 
TUS sorularını çözme oturumu $(p=0.008)$ ile ilgili önermelere verilen puanlar staj bitiminde daha yüksek bulundu. Meslektaş eğitim toplantısı $\quad(\mathrm{p}=0.016), \quad$ sağlık çalışanlarının karşılaşabileceği şiddete yönelik oturum $(p<0.001)$ ve TSM çalışmalarının pratikte gözlenmesine yönelik önermelere $(p=0.013)$ ise staj sonunda verilen puanların daha düşük olduğu bulundu. Sağlık müdürlüğü tanıtım oturumu ( $\mathrm{p}=0.850)$ ve asistan destekli seminer hazırlamanın faydasına $(p=0.802)$ yönelik önermelere verilen puanlarda bir değişiklik bulunamadi. Staj içindeki uygulamalar ve stajın genelinin, staj başlangıcında ve staj bitimindeki puan ortalamaları Tablo 1'de verildi.
Öğrencilerin \%62.9'u staj başlangıcında stajdan memnun kalacağını düşünürken, staj bitiminde memnun kaldığını belirten öğrenci yüzdesi \%73.1 olarak saptand $1(\mathrm{p}<0.001)$. 'Bilimsel araştırma süreci" ve "'teorik bilgi oturumları" gruplarındaki uygulamalardan memnuniyet staj bitiminde, staj başlangıcına göre daha yüksek bulundu $(\mathrm{p}<0.001)$. 'Sağlık hizmetleri ve uygulamalar" grubundaki uygulamalardan memnuniyet ise staj bitiminde, staj başlangıcına göre daha düşük bulundu $(\mathrm{p}<0.001)$. Öğrencilerin staj başlangıcında ve staj bitiminde memnuniyet yüzdeleri Tablo 2'de verildi.

\begin{tabular}{|c|c|c|c|}
\hline & $\begin{array}{c}\text { Staj başlangıcmda } \\
\text { memnun } \\
\text { kalacağımı } \\
\text { düișünenler }(\%)\end{array}$ & $\begin{array}{c}\text { Staj } \\
\text { bitiminde } \\
\text { memnun } \\
\text { kalanlar }(\%)\end{array}$ & $\mathbf{P}^{*}$ \\
\hline 1. Bilimsel Araștırma Süreci & 57.3 & 77.5 & $<0.001$ \\
\hline Literatür tarama becerisi & 65.2 & 85.9 & $<0.001$ \\
\hline Anket hazırlama becerisi & 65.2 & 75.0 & $<0.001$ \\
\hline Araştırma verisi değerlendirme & 63.6 & 78.3 & $<0.001$ \\
\hline Makale yazma becerisi & 45.1 & 76.6 & 0.012 \\
\hline Makale sunma oturumu & 47.3 & 71.7 & 0.024 \\
\hline 2. Sağlık Hizmetleri ve Uygulamalar & 73.2 & 65.6 & $<0.001$ \\
\hline Meslektaş eğitim toplantıs1 & 81.0 & 71.7 & $<0.001$ \\
\hline Sağlık Müdürlüğü tanıtım oturumu & 66.8 & 69.6 & $<0.001$ \\
\hline $\begin{array}{l}\text { Sağlık çalışanlarının karşılaşabileceğ } \\
\text { şiddete yönelik oturum }\end{array}$ & 75.0 & 60.3 & $<0.001$ \\
\hline TSM çalışmaları & 70.1 & 60.9 & $<0.001$ \\
\hline 3. Teorik Bilgi Oturumları & 60.3 & 74.6 & $<0.001$ \\
\hline Asistan destekli seminer hazırlama & 59.8 & 68.5 & $<0.001$ \\
\hline Etkin seminer sunma becerisi & 53.3 & 67.9 & 0.009 \\
\hline Salgın senaryosu çözme oturumu & 71.2 & 85.3 & $<0.001$ \\
\hline TUS soruları çözme oturumu & 60.9 & 76.6 & $<0.001$ \\
\hline Bölümdeki seminer oturumları & 56.5 & 74.5 & $<0.001$ \\
\hline Staj Değerlendirme Ölçeği Toplam Puanı & 62.9 & 73.1 & $<0.001$ \\
\hline
\end{tabular}

* Mc Nemar testi ile bulunan değer

Tablo 2. Öğrencilerin staj başlangıcında ve staj bitiminde memnuniyet yüzdelerinin karşılaştırılması

\section{Tartışma}

Çalışmada stajdan memnuniyet yüzdesinin ve staj değerlendirmesi için verilen puanların staj başlangıcına göre staj bitiminde arttığ bulundu. Trakya ve Marmara üniversitelerinde yürütülen benzer çalışmalarda Halk Sağlığı stajının, 
öğrencilerinin çoğunun beklentilerini karşıladığ1 ve belirtilen amaçlara ulaştığı rapor edilmiştir $(12,13)$. Halk Sağlığ 1 stajını yeterli ve faydalı bulan, stajdan memnun kalan öğrencilerin oranı \%48.8-\%89 arasında değişmektedir (11, 14-16). Dokuz Eylül Üniversitesi'nde 8 yıl boyunca süren benzer bir çalışmada öğrencilerin Halk Sağlığı stajına 5 üzerinden ortalama 4.4 puan verdikleri bildirilmiştir (17). Yorulmaz ve ark. intörnlerin çok büyük bir kısmının Halk Sağlığı eğitimini yeterli bulduğunu bildirirken, Aslan ve ark. yaklaşık yarısının orta ve yeterli bulduklarını rapor etmiştir $(18,19)$. Atçeken ve arkadaşlarının yaptığı çalışmada, öğrencilerin stajın gelecekteki mesleki yararına ve stajın genel özelliklerine 5 üzerinden ortalama 4.4 puan, staj hedeflerine ulaşmaya 3.1 puan verdiği bildirilmiştir. Aynı çalışmada öğrencilerin sadece \%38.4'ü Halk Sağlığı stajının hekimlik nosyonuna katkı sağladığını belirtmiştir (20). Çalışkan ve arkadaşlarının çalışmasında ise, öğrencilerin staj sonunda verdikleri yeterlilik puanlarının, staj başındaki beklenti puanlarından genelde daha düşük olduğu bildirilmiştir (21). Pabst ve arkadaşları tarafindan yürütülen, hekimlere lisans müfredatındaki derslerin tıp doktoru olma eğitimine ne kadar uygun ve ilgili olduğunun sorulduğu bir çalışmada, hekimlerin yaklaşık üçte biri Halk Sağlığı stajı için temel ve gerekli, yaklaşık yarısı ise biraz alakalı yanıtını vermiştir (22). Ülkemizde Halk Sağlığı stajına yönelik yapılan çalışmalarda öğrenciler en çok stajın ve dershanenin fiziksel koşullarından, iş ve eğitim yükünden yakınmaktadır (12, 18-20, 23). Çalışmaların farklı üniversitelerde yapılması, her üniversitedeki eğitimcilerin, staj içeriğinin ve staj ortamı fiziksel koşullarının farklı olması sebebiyle birbirinden farklı sonuçlar bildirilmiş olabilir.

Toplumdaki önemli sağlık problemlerini tespit etmek, bu sağlık problemlerinin özelliklerini ortaya koymak, nedenlerini belirlemek ve çözüme yönelik öneriler getirmek için sağlıkla ilgili epidemiyolojik araştırmaların yapılması önemlidir. Hekim adayları bu konudaki gerekli bilgi ve beceriyi Halk Sağlığı stajında deneyimlemektedirler. Ayrıca bu çalışmalardan elde edilen sonuçların ilgili yöneticilerle paylaşılması sorunların çözümü konusunda yardımcı olabilir. Çalışmada epidemiyolojik bir araştırma planlama, uygulama, raporlama ve sunma çalışmaları ile ilgili önermeler içeren "bilimsel araştırma süreci" grubuna verilen puanlar staj bitiminde, staj başlangıcına göre daha yüksek bulundu. $\mathrm{Bu}$ uygulamalardan memnuniyet yüzdesi de staj bitiminde daha yüksek olarak saptandı. Anabilim Dalımızda daha önceden yapılan bir çalışmada intörnlerin \%48.7'si staj başında bir araştırma planlayıp yürütebileceğini belirtirken, staj sonunda bu orantı \%86.2'ye yükselmiştir (24). Kılıç ve arkadaşlarının yaptığı bir çalışmada, öğrencilerin staj içerisindeki bilimsel bir araştırma planlama sürecine 5 üzerinden 4.4, araştırma yapmaya ise 4.5 puan verdikleri, diğer yandan Atçeken ve arkadaşlarının yaptığı çalışmada ise araştırma planlamaya 5 üzerinden 4.1 puan verirken, öğrencilerin ancak \%12.8'inin akademik çalışmalarla ilgili deneyim kazandıklarını belirttiği bildirilmiştir $(17,20)$. Stellman ve arkadaşlarının Halk Sağlığı yüksek lisans öğrencileri ile yaptıkları bir çalışmada da, öğrenciler en çok epidemiyoloji, biyoistatistik, araştırma tasarımı, organizasyonu ve süreci hakkında beceri kazandıklarını bildirmiştir (25). Çalışmada "sağlık hizmetleri ve uygulamalar" grubundaki etkinliklere staj bitiminde, staj başlangıcına göre daha düşük puan verildiği saptandı. Memnuniyet yüzdesinin de staj bitiminde düşmüş olduğu tespit edildi. Hekim 
aday1 öğrenciler Halk Sağlığ1 staj1 içinde eğitim araştırma bölgesindeki TSM'lere gitmekte, buralarda uygulamalı eğitim almakta ve pratik yapmaktadırlar. Birinci basamak sağlık hizmetlerinin işleyişini yerinde görmek açısından önemli olan bu uygulamaların bazı istenmeyen yanları da vardır. Karahan ve ark. tarafindan yapılan bir çalışmada öğrencilerin en çok toplum sağlığı ile ilgili kuruluşlara ulaşımın zorluğundan yakındıkları bildirilmiştir (13). Çalışma grubumuzda da, özellikle ilçelerdeki TSM'lere ulaşımın uzun sürmesi, ilçelerdeki TSM eğitimi süresince üniversiteye bağl1 lojmanlarda kalınması ve lojmanların fiziki koşullarından memnun kalınmaması, TSM'lerde her türlü uygulamanın görülememesi veya aktif olarak her uygulamada yer alınamaması gibi sebepler bu gruba verilen puanların staj sonunda daha düşük çıkmış olmasının nedenleri olabilir. Atçeken ve arkadaşları ASM ve TSM stajına 5 üzerinden 4.2 puan verildiğini bildirmiştir (20). Aksakal ve arkadaşları öğrencilerin yaklaşık yarısının, Aslan ve arkadaşları intörnlerin yaklaşık üçte birinin pratik eğitimi yetersiz bulduğunu bildirirken, Kocaeli Üniversitesi Tıp Fakültesi son sınıf öğrencilerinde yapılan bir çalışmada bu oran yaklaşık beşte birdir (14, 16, 19). Göçgeldi ve ark. tarafindan yapılan bir çalışmada en çok pratik uygulama yapma imkanı bulunan stajlar içinde Halk Sağlığı stajının \%7.4 ile beşinci sırada yer aldığı bildirilmiştir (26). Durduran ve ark. tarafindan yapılan bir çalışmada intörnlerin $\% 15$ 'i saha çalışması ve pratik uygulamalara daha çok yer verilmesi gerektiğini belirtmiştir (11).

Çalışmada "teorik bilgi oturumları" grubundaki uygulamalara verilen puanlar staj bitiminde, staj başlangıcına göre daha yüksek bulundu. Memnuniyet yüzdesinin de staj başlangıcına göre staj bitiminde yükseldiği tespit edildi.
Halk Sağlığı stajındaki çeşitli seminer oturumlarının değerlendirilmesi amacıyla yapılan çalışmalarda, öğrencilerin genellikle olumlu görüş bildirdikleri rapor edilmiştir (27, 28). Kocaeli Üniversitesi Tip Fakültesi son sınıf öğrencilerinin üçte ikisinin Halk Sağlığ1 staj1 teorik eğitimini yeterli bulduğu bildirilmiştir (14). Yorulmaz ve arkadaşlarının bir çalı̧̧masında öğrencilerin stajda en çok teorik derslerden faydalandığı, başka bir çalışmalarında ise öğrencilerin \%75.6'sının derslerin tümünü gerekli bulduğu rapor edilmiştir $(12,18)$. Atçeken ve arkadaşlarının yaptığ 1 çalışmada stajdaki kavramsal konulara 5 üzerinden 4.3 puan verildiği bildirilmiştir (20). Anabilim Dalımızda yapılan oturumlarda tartışılan teorik bilgiler, birinci basamakta çalışan bir hekimin bilmesi gereken, mesleki hayatında karşılaşacağı durumlara, görev, yetki ve sorumluluklarına ait bilgileri içermektedir. Bunun yanı sıra sadece birinci basamak çalışanlarını değil, tüm hekimleri ilgilendiren memur hukuku, iş yeri hekimliği, salgın, afet tıbbı ve bilimsel araştırma yapma konusunda seminerler de bulunmaktadır. Öğrenciler bu dersler kapsaminda seminer hazırlama ve sunma becerisi de kazanmaktadırlar. Ayrıca TUS'a hazırlanan bu öğrencilerle, Halk Sağlı̆̆ 1 TUS soruları çözülmekte ve Halk Sağlığ konuları TUS yönüyle gözden geçirilmektedir. $\mathrm{Bu}$ sebeplerden dolayı öğrenciler, dersleri beklediklerinden daha faydalı bulmuş olabilirler.

\section{Sonuç}

Öğrencilerin yaklaşık dörtte üçünün Halk Sağlığı stajından memnun kaldığı bulundu. Verilen puanların toplamı staj başlangıcına göre artış gösterdiğinden, öğrencilerin staj sonundaki yeterlilik değerlendirmeleri, staj başlangıcındaki beklentilerine ait değerlendirmelerinden daha 
yüksek puan aldığından dolayı stajın genel olarak öğrencilerin beklentilerini karşıladığ1 sonucuna varıldi.

Staj bitimindeki yeterlilik puanlarında düşüş tespit edilen oturum ve uygulamalardaki eksikliklerin tespit edilip, öğrencilerin geri bildirimleri değerlendirilerek, yeni staj gruplarının eğitimlerinin bu yönde planlanmasının uygun olacağı kanaatine varıldı. Birinci basamak koruyucu sağlık hizmeti uygulamalarının yerinde görülmesi açısından stajın en önemli uygulamalarından olan TSM çalışmalarına verilen puan ve memnuniyet staj sonunda staj başlangıcına göre daha düşük bulundu. $\mathrm{Bu}$ durumun incelenmesi için, stajdaki TSM uygulamalarının ayrıntılı olarak değerlendirilmesine yönelik yeni bir çalışma planlandı. Teorik destekli pratik eğitimin arttırılması ve iyileştirilmesi gerektiği düşünüldü. Staj başlangıcında, Halk Sağlığı stajının amaç ve hedeflerinin anlatıldığı bir staja hazırlık oturumunun yapılmasının faydalı olacağı kanaatine varıldı. Tıp eğitimi içinde yer alan stajlarda, stajın eğitim programlarını içeren değerlendirme anketlerinin oluşturulması ve staj öncesi ve staj sonrasında uygulanmas1, stajların daha eğitici olmalarında kullanılabilir ve stajların geliştirilmesine katkı sağlayabilir.

\section{Kaynaklar}

1. Mezuniyet Öncesi Tıp Eğitiminde Halk Sağlığı Eğitimi: Halk Sağlığı Uzmanları Derneği; 2014 [Erişim tarihi: 04.12.2018]. Erişim adresi: http://halksagligiokulu.org/ anasayfa/components/com_booklibrary/ebooks/ MEZUNIYET\%20ONCESI\%20HALK\%20 SAGLIGI\%20EGITIMI.pdf. 2. Bahar-Ozvaris S, Sonmez R, Sayek, I. 504.
Assessment of knowledge and skills in primary health care services: senior medical students' self-evaluation. Teaching and Learning in Medicine. 2004;16(1):34-38.

\section{Gürpınar E, Musal B, Aksakoğlu G. Dokuz} Eylül Üniversitesi Tip Fakültesi'nde Halk Sağlığı rotasyonu yapan dönem VIöğrencilerinin toplum hekimliği konularındaki bilgi düzeyleri. Tıp Eğitimi Dünyası. 2003;13(13):59-64.

4. Hobson W. Theory and Practice of Public Health. New York Toronto: Oxford University Press; 1979.

5. Gillam S, Maudsley G. Public health education for medical students: rising to the professional challenge. Journal of Public Health. 2009;32(1):125-131.

6. Gillam S, Bagade A. Undergraduate public health education in UK medical schoolsstruggling to deliver. Medical Education. 2006;40(5):430-436.

7. Tyler IV, Hau M, Buxton JA, Elliott LJ, Harvey BJ, Hockin JC at al. Canadian medical students' perceptions of public health education in the undergraduate medical curriculum. Academic Medicine. 2009;84(9):1307-1312.

\section{Rosenstock L, Helsing K, Rimer BK. Public} health education in the United States: then and now. Public Health Reviews. 2011;33(1):39-65.

9. Kılıç B, Şahan C, Bahadır H. Dünyada ve Türkiye'de halk sağlı̆̆ uzmanlık eğitiminin tarihçesi, içeriği ve istihdam politikaları. TAF Preventive Medicine Bulletin. 2014;13(6):495- 
10. Sağlıkta dönüşüm programı içinde toplum sağlığı merkezleri'nin yeri panel kitabı. Eskişehir: ESOGÜ Basımevi; 2014.

11. Durduran Y, Saltuk Demir L, Uyar M, Savaş Duman Ç, Şahin TK. Bir tıp fakültesinde çalışmaya katılan intörnlerin "halk sağlığı" stajı ile ilgili bazı görüşleri. 17. Ulusal Halk Sağlığ Kongresi; 20-24 Ekim 2014. 1442.

12. Yorulmaz F, Gökçen Selçuk E, Baysal S. Trakya Üniversitesi Tıp Fakültesi altıncı sınıf öğrencilerinin halk sağlığı staj1 hakkındaki değerlendirmeleri. 19. Ulusal Halk Sağlığ Kongresi; 15-19 Mart 2017. 515.

13. Karahan A, Kesmezacar Ö, Kalaça S, Çalı Ş. Marmara Üniversitesi Tıp Fakültesi son sınıf öğrencilerinin halk sağllğı stajı konusundaki düşünceleri. 3. Ulusal Tip Eğitimi Kongresi; 1216 Nisan 2004. 139.

14. Kocaeli Üniversitesi Tıp Fakültesi Son Sınıf Öğrencilerinin Eğitimlerini Değerlendirmesi: Kocaeli Üniversitesi Tıp Fakültesi; 2013 [Erişim tarihi: 02.05.2018]. Erişim adresi: http:// tip.kocaeli.edu.tr/docs/raporlar_sunumlar/tip_ egitimi_arastirmasi2013.pdf.

15. Şahin H. Eğitim programı değerlendirmede öğrenci geribildirimleri ve kritik olaylar tekniğinin kullanılması: halk sağlığı intörn staj program. Tıp Eğitimi Dünyası. 2007;24(24):18.

16. Aksakal FN, Özkan S, Özdil A. Bir tıp fakültesinde beşinci sınıf öğrencilerinin halk sağlığı stajı eğitim programını değerlendirmesi. 3. Ulusal Tip Eğitimi Kongresi; 12-16 Nisan 2004. 149.
17. Kılıç B, Ergör A, Demiral Y, Uçku R, Ünal $\mathrm{B}$, Günay $\mathrm{T}$ ve ark. Dokuz Eylül Üniversitesi Tıp Fakültesi son sınıf öğrencilerinin halk sağlığ 1 rotasyonuyla ilgili geri bildirimlerinin değerlendirilmesi (1998-2006). Tip Eğitimi Dünyası. 2007;24(24):9-15.

18. Yorulmaz F, Ergüden Kendirlinan Ş, Mavili S, Şahin A, Gül İ. Trakya Üniversitesi 20132014 dönemi intörnlerinin tıp ve halk sağlığ 1 eğitimi hakkında görüşleri. 17. Ulusal Halk Sağlığı Kongresi; 20-24 Ekim 2014. 1200-1201.

19. Aslan S, Bideci A, Özkan S, Türkçüoğlu S, Çakır N, Dursun A ve ark. Bir tıp fakültesindeki intern doktorların dönem 6 eğitimleri süresince aldıkları stajlar hakkındaki geribildirimlerinin değerlendirilmesi. Tip Eğitimi Dünyası. 2006;23(23):19-26.

20. Atçeken İ, Açıkgöz ME, Yılmaz E, Demirtaş $H$, Eslek H, Sevindik M ve ark. Halk sağlığ 1 stajının intörnler tarafından değerlendirilmesi. 18 Ulusal Halk Sağlığ 1 Kongresi; 05-09 Ekim 2015. 580-581.

21. Çalışkan S. Ege Üniversitesi Tıp Fakültesi altınc1 sınıf öğrencilerinin halk sağlığı staj1 hakkındaki beklenti ve yeterliliklerinin değerlendirilmesi. 2. Ulusal Tip Eğitimi Kongresi; 24-28 Nisan 2001. 154.

22. Pabst R., Rothkötter HJ. Retrospective evaluation of undergraduate medical education by doctors at the end of their residency time in hospitals: consequences for the anatomical curriculum. The Anatomical Record: An Official Publication of the American Association of Anatomists. 1997;249(4):431-434. 
23. İlhan MN, Özkan S, Özdil A. Bir halk sağlığ1 staj1 eğiticileri ve eğitim ortamının değerlendirilmesi. 3. Ulusal Tıp Eğitimi Kongresi; 12-16 Nisan 2004. 148.

24. Iş1ktekin Atalay B, Öztürk Emiral G, Önsüz MF, Işıklı B, Metintaş S. Tıp fakültesi intörn doktorlarının halk sağlığı stajı ile ilgili düşünceleri. 19. Ulusal Halk Sağlığı Kongresi; 15-19 Mart 2017. 512.

25. Stellman JM., Cohen S, Rosenfield A. Evaluation of a one-year Masters of Public Health program for medical students between their third and fourth years. Academic Medicine. 2008;83(4):365-370.

26. Göçgeldi E, İstanbulluoğlu H, Uçar M, Yaren H, Ceylan S, Koçak N. Tıp fakültesi 5. ve 6. sınıf öğrencilerinin tıp eğitimleri süresince pratik uygulama yapabilme durumunun araştırılması. Gülhane Tıp Dergisi. 2011;53(2):107-113.

27. Özcebe H, Attila S, Bağc1 T, Aslan D. Hacettepe Üniversitesi Tıp Fakültesi Halk Sağlığı Anabilim Dalı'nda son 8 ayda staj yapan intörn doktorların katıldıkları çocuk sağlığı seminerleri ile ilgili görüşleri. 2. Ulusal Tıp Eğitimi Kongresi; 24-28 Nisan 2001. 158.

28. Özvarış ŞB, Aslan D, Koçoğlu GO. İntern doktorların sağlık eğitimi seminerleri ile ilgili görüşleri. 2. Ulusal Tıp Eğitimi Kongresi; 24-28 Nisan 2001. 159. 